\title{
The Role of Religious Elite to The Young Generation Education to Increase The Harmony of Interreligious People
}

\author{
$1^{\text {st }}$ Apeles Lexi Lonto \\ Pancasila and Civic Education \\ Department \\ Social Science Faculty \\ Universitas Negeri Manado \\ Tondano, Indonesia \\ lexi.lonto@unima.ac.id \\ $4^{\text {th }}$ Recky H. Sendouw \\ Public Administration \\ Department \\ Social Science Faculty \\ Universitas Negeri Manado \\ Tondano, Indonesia \\ reckysendouw@unima.ac.id
}

\author{
$2^{\text {nd }}$ Theodorus Pangalila \\ Pancasila and Civic Education \\ Department \\ Social Science Faculty \\ Universitas Negeri Manado \\ Tondano, Indonesia \\ theopangalila@unima.ac.id \\ $5^{\text {th }}$ Maxi Ventje Keintjem \\ Pancasila and Civic Education \\ Department \\ Social Science Faculty \\ Universitas Negeri Manado \\ Tondano, Indonesia \\ theopangalila@unima.ac.id
}

\author{
$3^{\text {rd }}$ Telly D. Wua \\ Pancasila and Civic Education \\ Department \\ Universitas Negeri Manado \\ Tondano, Indonesia \\ telly.wua@unima.ac.id
}

\begin{abstract}
The purpose of this study is to determine the role of religious elites in fostering the younger generation to increase the harmony of life among religious believers. By this research social conflict can be minimized, and knowing what factors cause the potential for harmony and the potential for non-harmony or social conflict in the life of a pluralistic society in North Sulawesi. The method used is a qualitative descriptive method. Moreover, data collection techniques are interview techniques, literature studies, and documentation. The results of the study show that the role of the religious elite in fostering the younger generation to increase inter-religious harmony is quite useful. This is evidenced by changes in the attitudes and mentality of the young generation so far there have been no fights between youths of different religions and tribes. To prevent potential conflicts between religious communities and especially the younger generation, religious leaders and leaders through the BKSAUA communication forum are always anticipatory and play an active role in carrying out dialogue and collaboration to discuss social issues, especially those that lead to racial problems. The harmony can be maintained so that the community can live together, side by side with one another, respect and respect, uphold the values of kinship with the spirit of "Torang Samua Basudara".
\end{abstract}

Keywords-religious elites, coaching, the young generation, harmony

\section{INTRODUCTION}

Indonesia is one of the nations in the world whose society is very pluralistic. The pluralism of the community is characterized by the existence of various cultures, languages, ethnic groups, ethnicities, groups, customs, and religions. Indonesian pluralism has distinctive characteristics from other nations because pluralism is not built by small primordial bases, but by the cultural philosophy of Bhinneka Tunggal Ika which is a reflection of the identity of the Indonesian nation. The diversity of the nation is fascinating to study from a variety of scientific approaches, for example, from legal, economic, social, political and anthropological approaches [1].

Such pluralism needs to be addressed wisely and wisely by all components of the nation, including the religious elite. Religious elites are the best people or choices in a religious group or a small group of prominent people in religious groups. Improper handling, such as being dishonest and unfair, to the reality of pluralism will turn into a source of catastrophe that can destabilize the integrity and safety of the nation. Pluralism has excellent potential as a source of conflict if the differences are increasingly sharpened and out of control. Conflict will occur if it is not directed at consensus efforts and healthy reconciliation. In fact, the situation of this conflict was increasingly high in intensity and eventually exploded into an anarchic act. The anarchic action is for example actions that are disruptive because there is no regulation or order in the country.

In recent years there have been conflicts between groups, both in the form of inter-ethnic conflicts, interreligious conflicts, and other conflicts. The conflict in several regions has developed; some even lead to mass riots. One of the various forms of mass riots that have tended to increase recently is riots involving different religious groups. This fact can be seen, among others: the conflict between religious adherents in Situbondo, Ketapang, Tasikmalaya, Maluku, Mataram, Kupang, Sambas and Poso and Palu.

Social upheaval in the form of mass riots lately shows that something is wrong in the order of political, economic, socio-cultural and defense security, and injustice because the rule of law is not implemented correctly so that it becomes one of the factors causing social upheaval in Indonesia. The recent riots in various regions in Indonesia, 
the masses of which are mostly or most are young people (youth groups), in addition to burning and destroying shops, people's homes, as well as places of worship, among others: the Church. Destruction and burning of the place triggered hostility between religious groups which initially lived in harmony and peace.

Various acts of violence incarnated in the form of mass anger (which are mostly young generation) have occurred in recent years with increasingly worrisome conditions. The mass violence was characterized by acts of mobility, destruction, persecution and even murder. Such acts of violence certainly tarnish the spirit of national unity and unity that has been held in high esteem, so it is natural that various parties try to make statements and analysis in order to find explanations and at the same time solutions to these problems [2].

Thus, it is necessary to create a healthy atmosphere, to enable the young generation to develop naturally and responsibly. Therefore, efforts need to be made to foster young generation by religious elites to provide an understanding of the meaning of Indonesian pluralism and involve it in the process of national and state life and the implementation of national development [3].

There is a rather classic saying: who will master the youth will master the future; or a nation that controls the younger generation will master the future." The saying implies that the position of the young generation in a country is significant. In a developing country like Indonesia, the role of the younger generation as the next generation is in a very strategic position and determines the future of the nation. Therefore, it is necessary to sustainably develop the young generation so that their role and role will become more evident in the national development process, which in turn will increase national security for the survival of the nation and state.

According to [4], the development of the young generation is carried out to maintain the continuity of the nation's existence, because if there is no coaching of the younger generation, there will be a generation that cannot answer the challenges of the environment, including relaxed youth. As has happened in some regions lately, mass anger involving young people is signifying the inability of the younger generation, especially the youth age group in answering the challenges of their environment, even if it is not overcome it will create national disintegration.

In this regard, the current generation of young people is considered very important and urgent to be realized. Assessment of the younger generation, especially in its position as a national development actor, is fascinating. The younger generation is an integral part of national life. Youth are categorized as the most substantial population with idealism and interpretation of high cultural values, such as noble ideals, pioneers, and drivers of progress, wanting change and renewal and always oriented towards the future.

The younger generation generally holds a strategic position in the development of a nation, which is expected to contribute optimally to national development. Therefore, the development of the younger generation needs to be directed to the development of human resources as development people both in the leadership strata and their actions in various aspects of the life of the nation and state, namely political, economic, socio-cultural and defense and security.

Realizing how important the role of young people is in realizing the historical heritage and in advancing the dignity and existence of the nation, every effort in the context of upholding the existence of the nation and state indeed requires active youth participation. To realize this participation, there needs to be a conception of the roles, positions, attitudes, and perceptions through fostering the younger generation, especially in responding to the SARA problem (ethnicity, religion, race, and class) which today is always a central issue by the mass media. This problem is closely related to the issue of national resilience because it involves dignity, the existence of the survival of the nation and state (2).

The religious elite must appear in their strategic roles and positions in order to deal with the actual problems of the people of the nation who are experiencing conflict. The religious elite is expected to play a real and useful role in building a conducive religious atmosphere. The role of religious elites is useful to prevent the spread of conflicts with religious nuances while at the same time they can renew people's lives from various deviant behaviors in the name of religion or use religious symbols for narrow interests that distort the religious life and integrity of the nation. Religious elites, therefore, must have spiritual integrity, namely religious attitudes that are inseparable from personality and accompanied by respect for all people in the beliefs and attitudes of life that they believe. The religious elite is responsible for renewing and straightening the direction of religious life from a variety of narrow interests. Religious elites should spearhead religious life that is full of dialogical zeal and works together in the context of real social life.

The position and role of religious elites in North Sulawesi are significant and urgent in building religious dialogue and fostering the younger generation to overcome social conflicts with religious nuances. North Sulawesi which is an integral part of the territory of the Republic of Indonesia is also not spared from social conflict. Nonetheless, the conflict between the two different religious groups that occurred in the city of Manado on March 14, 1970, was successfully handled by the religious elite so that it did not extend to other areas in North Sulawesi (Manado City BKSAUA Presidium) [3].

Local religious elites have a strategic position and role in directing and fostering their people, especially the younger generation, and can contribute their minds to achieving a broad solution to the nation's problems. Local religious elites have at least succeeded in building a religious life that is loving, joyful, and peaceful among their people so that they can overcome conflicts between religious groups and build religious life well. Starting from the background of the problem or problem above, the formulation of the title of this research is: "The Role of Religious Elites Against Youth Development in Efforts to Increase the Harmony of Interfaith Religion in North Sulawesi."

\section{RESEARCH METHODS}

Researchers in the study using the approach The method used in this study is a qualitative descriptive method, meaning that the data obtained in the form of words and not 
a series of numbers. Data collection techniques are carried out with a qualitative approach. A qualitative approach is chosen to reveal various empirical facts related to the context of understanding the problem of the role of religious elites in fostering the younger generation as an effort to increase religious harmony. The data obtained in this study are primary and secondary data, with literature study techniques, interview field studies, and documentation.

\section{RESULTS AND DISCUSSION}

This section discusses the role of religious elites in fostering the younger generation in order to increase the harmony of religious life in North Sulawesi. Alternatively, in other words, the following analysis provides an overview of the various realities about the role of the religious elite in fostering the young generation to create and maintain the harmony of life among religious believers in North Sulawesi.

In general, the development of the younger generation by the religious elites in North Sulawesi is quite useful, even though the guidance is not yet explicitly implemented and programmed both in the respective religious institutions, BKSAUA, local governments, and other relevant institutions.

To anticipate things that are not desired by all people, especially in the city of Manado, the young generation in each sub-district, often carry out various activities in the form of interfaith youth dialogue. By the results of previous research by [5], in Molas Subdistrict, for example, the young generation formed a joint committee for Eid al-Adha $1419 \mathrm{H}$ echo, which involved Church youth and youth Mosques as far as Molas District, which was carried out almost every year. This activity is carried out by the younger generation of the Church and the young generation of the Mosque with the spirit: "Torang Samua Basudara," which is the motto and philosophy of life of the people of Manado, and North Sulawesi generally.

Living Conditions of Religious People in North Sulawesi North Sulawesi Province is one of the regions in Indonesia that has a pluralistic or heterogeneous population; has pluralism regarding ethnicity, religion, race, and class. Adherents of religion in this region consist of various ethnic groups, both those from North Sulawesi and other regions in Indonesia. Religious pluralism in North Sulawesi can be seen clearly in the varied composition of the number of religious followers. Based on data obtained from the North Sulawesi Regional Statistics Agency (latest data 2018), the number of Protestants is $61.45 \%$, Islam $31.64 \%$, Catholics $5.81 \%$, Hindus 5.81\%, Hindus $0.93 \%$, Buddhists $0.11 \%$, Confucian $0.05 \%$.

The reality of life among religious believers in North Sulawesi cannot be separated from worship facilities and infrastructure. The houses of worship were built and cared for jointly by the followers of the religion concerned and by the community. Not only to this extent, but the location of places of worship of each religion are also close together, for example, a Protestant Church is standing opposite the Mosque; so do others, places of worship of different religions, standing close together, even side by side with other religious places of worship. There is also one village, the majority of which are Muslims, in the village stands the Protestant Church. This church also faces Mosques and
Islamic school villages. This village in the city of Manado is better known as Kampung Islam, apparently not only merely a place of worship that embraced Islam but also the Church, a place of worship that Protestant religion stands firmly there. Likewise, in Tomohon City there is a mosque built in the middle of Tomohon City which is a Christian and Catholic neighborhood; to the north of Tomohon City, in the village of Kinilow, which has a Christian and Catholic population, precisely at the entrance of Tomohon City, mosques and boarding schools are also built. This reality strongly shows that their harmony in building places of worship and using them by their respective religions. In Minahasa District known as the land of the Gospel because the population is mostly Christian and Catholic, both in the sub-district and villages, there are also many places of worship found beside the Church, in the form of Mosques, Temples, and Vihara. In some sub-districts in Minahasa, there were also found Islamic villages, Kampung Jawa, which were surrounding villages that were Christian and Catholic.

Observations made during this research show that the atmosphere of life among religious believers in North Sulawesi is reasonable and reasonable. Not with a heavy heart if people say that normality is also a sign of harmony in religious life. Each religious group looks active, safe, and free to carry out religious activities such as worship, spiritual formation, and social activities. Their respective places of worship and religious education institutions are safe and free to carry out their functions.

Social relations between individuals and between religious groups continue to take place, both formally and informally. Formal relations between religious believers can be seen, among others: from their presence together in religious ceremonies, for example: in the Christmas celebration, the Ecclesiastical Assembly, the religious choir party (Pesperawi), Halalbihalal, MTQ and so on. In fact, it is also seen that there is much spiritual coaching that is being carried out, both in government and private institutions towards religious groups in the relevant institutions.

This reality exists not merely by itself. The role of the religious elite is essential in the realization of the harmony. The religious elite is a government and private institution, for example by opening up the harmony of life among religious believers. The mobilization was realized through formal agencies' events, for example, when Christmas Day arrived, officially it did not take into account the holy religion embraced, the different guests came together to celebrate. Not only people who are invited, but agency employees and their family members also come. In fact, there was also the Chair of the Christmas Day Committee who was a Muslim; on the contrary, when the Halal Bihalal event was officially held in government and private institutions, the event was also attended by guests with different religious backgrounds, not limited to only Muslims. This reality is one example of the horizontal relationship between religious groups there, both seen formally and informally.

Informal relations between religious believers, for example in the cities of Manado, Minahasa, Lota, Tomohon, Bitung, Bolang Mongondow, Sangir, and Talaud, can be seen from the activities of religious people who visit each other and shake hands on religious holidays, such as Christmas and Eid al-Fitr. Every member of the community, 
both Muslim and Christian, seems to mingle with each other in carrying out daily activities, both in the market, at school, in the office, and other places.

The development that has taken place so far shows that fostering inter-religious harmony can be said to be quite useful. Coaching the harmony is of course played by the religious elite.

The establishment of harmony among religious believers in the lower levels is also determined by the religious attitudes and views of religious elites/figures. The lower society generally tends to imitate those in elite positions. A tradition that can be lifted from the example of community life in Gorontalo and Bolaang Mongondow. The government elites and religious elites who are Christians in this area generally have a brotherly relationship that is very familiar with their Muslim brothers.

This intimate relationship reflects the attitude of Torang samua basudara, regardless of any religious background adopted. Another example is seen in MTQ religious activities; the committee involved young Christian youth. Likewise, Christian religious activities such as Pesparawi, the 10th Indonesian Council of Churches (DGI) General Assembly involved young people and Muslim youth in the committee. The elite factor is once again very influential in reducing the issue of SARA.

The success of religious harmony in North Sulawesi has developed in traditional residential environments through the association of everyday life that is always familiar among people of different religious communities. The maintenance of harmony between harmonious religious communities, this can be seen in the practice of daily life that shows the giving of those who are in excess to those who are in need seems to cause excessive suspicion among religious people [6].

The attitude of the Manado people who are very open in their association and do not consider the origin of a person can foster a more harmonious inter-harmony. Understanding religious teachings correctly is the key to creating relationships that remind each other.

The harmony of religious life in North Sulawesi is characterized by two factors, namely the potential factors of harmony and potential factors of disharmony. In general, it is recognized by the religious elite, that the harmony of life between religious believers is inseparable from the existence of social conflict as a characteristic of a pluralistic society. Uncontrolled social conflict will have the potential for disharmony which has an impact on regional stability. It required the elite religious role in nurturing the younger generation effectively and continuously periodically or gradually and programmed to create continually condition of society in harmony and peace.

Two dominant factors must be considered by religious elites in the implementation of coaching to the younger generation, as follows.

\section{A. Potential factors of religious harmony}

The tradition of the life of the people of North Sulawesi who lived for generations and was relevant to the principle of harmony was used by the religious elite to reconcile the people. The tradition was in Minahasa is mapalus culture or mutual help and life motto: Torang Samua Basudara (we are all brothers). Mapalus is a living tradition of Minahasa people who have united people's lives without discriminating between religion, class, or social and economic status. Mapalus is a social spirit that unites vision and joint activities in building a life together. That is if the motto of Torang Samua Basudara lay the basis of the public's view of the nature of its existence as a group of brothers. Mapalus is more a real implementation of the slogan on social activities in the framework of developing various aspects of life. Both of these cultural potentials have succeeded in building community resilience and creating discipline and social order in the face of the current global civilization that is full of competition [1].

The real potential of harmony is the willingness to cooperate, and the willingness to carry out dialogue between religious groups is quite useful. If other religions establish a place of worship in the majority community in one environment, no one feels objection and the seventh if there is a group of minority communities who want to establish a place of worship.

The level of public awareness to view as brothers and family to adherents of other religions is right. According to them, the order of society in Manado is quite substantial and robust and is built by brotherhood, so that the efforts of provocateurs to compete between religions have always failed. The kinship that is intertwined through inter-ethnic mating processes is quite good. In other words, the capital of the people of Manado and North Sulawesi in general in maintaining stability and harmony during this time is based on the spirit of "Torang Samua Basudara" as the slogan of the life of the North Sulawesi "Nyiur Melambai" community.

Feeling safe living in an environment with a majority of other religions and being able to adapt to their customs is an objective recognition of the religious figures interviewed. This shows that most people feel safe living in the majority of other religions and they can adjust to their customs. The reason given by the respondents was that there had been no interference from other religious parties even though the situation was heating up in Indonesia, with the emergence of riots that smelled of racial violence in various places, for example in Sambas, Ambon, Ternate, Mataram, Poso, and others. In fact, the people, both Islam, Christianity, Buddhism and Hinduism, agreed to look after each other and secure their homes, especially places of worship, such as when Christians worship on Sundays, Muslim youths who guard the surrounding churches. On the contrary, if the turn of the Muslims is to carry out their prayers on Friday, then the Christian youth who guard the security around the Mosque.

Holding visits to homes during religious holidays from followers of other religions always colored the lives of religious people in North Sulawesi. This shows the level of public awareness to attend the commemoration of religious holidays from followers of other religions, is quite good. The reasons given by respondents were as fellow citizens and neighbors or friends, it was an obligation to visit each other, shake hands, say hello to brothers and sisters of other religions celebrating holidays such as Christmas and New Year, Idul Fitri, Waisak, Nyepi, and other religious ceremonies. 
The attitude that appears in social life in the community is mutual respect and respect and attending invitations to the thanksgiving of neighbors of different religions. This means that most people understand the relationship in their daily lives, both with religion and with different religions. The reason given by the respondent is that as a civilized fellow human being, it is imperative for each adherent of religion to respect other people and to attend a neighbor's Thanksgiving event regardless of religious differences or social status. Who does not associate, as a result, he will be ostracized by the community.

Willingness to contribute to religious activities or build places of worship to neighbors who are of different religions is often carried out by people in North Sulawesi. This shows that the level of public awareness contributes in the form of money for religious activities or building places of worship, is relatively high. The reason given by respondents is that it has become a habit of the people of Manado to contribute to each other both in religion and in different religions. The same thing was justified by the five leaders of religion when the authors interviewed them at different times and places. They acknowledged that every religious holiday was indeed a request for community donations which were used to help the poor, widows, orphans from various social foundations of each religion. This kind of social activity among Christians is called "diakonia" as a concrete manifestation of Church love and service to fellow human beings. Moreover, among Muslims, it is called "charity" or "charity" to ease the burden of the needy or the poor (fellow human beings).

Community service activities and social gathering (RT) and community units (RW) between religious believers are also lively carried out by the people in North Sulawesi, especially in Manado and Minahasa. This means that public awareness for the organization is good.

\section{B. Potential Factors of Inter-religious Interreligious Life}

In the life of religious people in North Sulawesi, in addition to the harmony factor, various factors of dishonesty or inhibiting factors were found. Factors that have the potential to hinder the development of religious communities can be macro or micro, both developing at the local and national levels. The factors of religious conflict, also found in communities in North Sulawesi are as follows:

First, social stratification or coating and social density of life in society, such as differences in level or socioeconomic status between religious adherents or leaders. This social stratification and social density are factors that are strong enough to influence other factors because they are complex and structural;

Second, economic and political interests between groups and individual elites and religious adherents. According to him, every community group, including religious adherents and leaders of every religious group, have the same interest in fighting for the sources of economic and political life as critical social needs; including infighting over political power assets, such as being a member of the House of Representatives, being a member of the government bureaucracy, and so on. This interest is influenced by the level of social stratification of each religious group or leader;

Third, differences and interpretations of religious teachings, which among others give rise to excessive fanaticism towards the religious schools or ideals adopted by each religious group in the same internal religious environment, both at the level of the people and leaders. This difference in the land is also related to the conditions of social stratification and economic and political interests between groups or religious leaders in the same internal religious environment;

Fourth, the mobility of activities, including efforts to maintain or expand the number of pilgrims who are followers of the propaganda or movement carried out by each religious group in the same religious community, including in carrying out social mobility groups, especially the elites. The quality and quantity of this type of mobility is influenced by factors of social stratification, economic and political interests, and religious ideology in each religious group;

Fifth, religious beliefs are fundamental beliefs and are considered absolute regarding the primary commitment of diversity, which is sacred and fundamental for every religion;

Sixth, communication barriers that often occur in the life of religious believers due to the imposition of will on other religions and limited knowledge among religious communities. Thus their activities in interpreting the teachings of other religions tend to be negative.

Also, other incoherence factors such as excessive suspicion are also found in the lives of religious people; as stated by [7], the inhibiting factor in fostering religious communities that should be noted by religious elites is a factor of suspicion. Suspicion in interaction is due to a beautiful view of other groups, or negative stereotypes that tend to be ingrained. Suspicion is also caused by deterministic beliefs that only the views of the group itself are correct and that the views of other groups are fundamentally wrong and evil so there is no place for an attitude imbued with a sense of tolerance.

Thus it can be said that the relationship between religious believers in Manado and North Sulawesi in general, has so far been recognized as wholly good and there has never been a physical conflict between Christianity and Islam, Buddhism, and Hinduism. However, that does not mean no potential conflict leads to the division; for example, the relationship between Christianity and Islam, as an example that can be put forward, where the two adherents of this religion raise issues, suspect one another and accuse each other of attempts at Christianization and Islamization.

In religious life in North Sulawesi, the religious elites interviewed acknowledged and confirmed the existence of potential conflicts in the form of dark leaflets, even in other ways that contained Christianization and Islamization efforts; mutual suspicion between followers of religion.

The use of loudspeakers in places of worship such as mosques and Church canteens, is also an indicator of the potential for inter-religious disharmony, more specifically among Muslims and Christians. Another problem found in the lives of religious people in Manado is sermons at the time of worship/prayer. It is also acknowledged by the public that there are still sermons in places of worship/prayers that make others feel offended. 


\section{CONCLUSION}

Based on the results of the research that has been analyzed and described in the discussion above, it can be concluded as follows that the development of the younger generation by religious elites in the form of lectures/sermons, both in their respective religious institutions, BKSAUA, and related institutions in North Sulawesi is quite good and useful, although it is acknowledged that it is not implemented programmatically and not individually.

\section{ACKNOWLEDGMENT}

We would like to say thanks to the Rector of Manado State University and also to our fellow research team and writers. Thanks also to the Committee of International Conference on Social Science (ICSS) and the Atlantis Press Publisher which has facilitated the publication of this article..

\section{REFERENCES}

[1] T. Pangalila, Ngarawula, Bonaventura, and K. Sadhana, "Tolerance behavior among society in city of Tomohon, North
Sulawesi," Int. J. Humanit. Soc. Sci. Res., vol. 4, no. 4, pp. 4649, 2018.

[2] H. Nugroho, "Religion, National Pluralism and Resilience: An Effort to Deny the Determination of Social Unrest. Paper: About Religion and National Resilience Building/Agama, Kemajemukan dan Ketahanan Nasional. Makalah: Sebuah Upaya Menolak Determinan Kerusuhan Sosial," Tannas Pascasarjana UGM, Yogyakarta, 1997.

[3] A. L. Lonto, Peran Elite Agama Dalam Membina Kerukunan Hidup Antarumat Beragama di Kota Manado/The Role of Religious Elite In Building Religious Interfaith Living in Manado City. Malang: Wineka Media, 2003.

[4] B. Simandjuntak and I. L. Pasaribu, Membina dan Mengembangkan Generasi Muda. Bandung: Tarsito, 1980.

[5] E. Lumowa, "Pola Pembinaan Generasi Muda Dalam Rangka Peningkatan Hubungan antarUmat Beragama Dalam Konteks Ketahanan Nasional: Suatu Studi di Kota Manado Sulawesi Utara," Universitas Gadja Mada, 2000.

[6] T. Pangalila, "Pengaruh internalisasi nilai budaya Si Tou Timou Tumou Tou, Mapalus dan Torang Samua Basudara Dalam Pembelajaran PKn Terhadap Peningkatan Sikap Toleransi Siswa: Penelitian Survey Terhadap Siswa SMA di Kota TomohonSulawesi Utara," Universitas Pendidikan Indonesia, Bandung, 2013.

[7] Koentjaraningrat, "Kecurigaan Adalah Hambatan Bagi Integrasi," Majalah Prisma, Jakarta, 1997. 